\title{
PROCESS INTENSIFICATION AT NEAR NEUTRAL pH OF A HOMOGENOUS PHOTO-FENTON REACTION USING FERRICARBOXYLATE COMPLEXES: APPLICATION TO OXYTETRACYCLINE DEGRADATION
}

\author{
J.H.O.S. PEREIRA ${ }^{1,2}$, D.B. QUEIRÓS ${ }^{3,4}$, A.C. REIS ${ }^{1,5}$, O.C. NUNES ${ }^{1,5}$, M.T. BORGES ${ }^{3,4}$, \\ R.A.R. BOAVENTURA ${ }^{1,2}$, V.J.P. VILAR ${ }^{1,2^{*}}$ \\ ${ }^{1}$ University of Porto, Faculty of Engineering, Chemical Engineering Department \\ ${ }^{2}$ LSRE - Laboratory of Separation and Reaction Engineering, \\ ${ }^{3}$ University of Porto, Faculty of Sciences, Biology Department \\ ${ }^{4}$ CIMAR - Centre for Marine and Environmental Research \\ ${ }^{5}$ LEPABE - Laboratory of Process Engineering, Environment, Biotechnology and Energy \\ *Corresponding author: vilar@fe.up.pt
}

\begin{abstract}
This work demonstrates the application at near neutral $\mathrm{pH}$ of the photoFenton process mediated by ferricarboxylates on the treatment of aqueous solutions containing the antibiotic Oxytetracycline (OTC) under solar irradiation. The formation of a Fe:OTC complex after $\mathrm{Fe}^{2+}$ oxidation to $\mathrm{Fe}^{3+}$, in the presence of $\mathrm{H}_{2} \mathrm{O}_{2}$, showed the inconvenience of using the conventional $\mathrm{Fe}^{2+} / \mathrm{H}_{2} \mathrm{O}_{2} / \mathrm{UV}-\mathrm{V}$ is process at near neutral $\mathrm{pH}$ levels, as the Fe:OTC complex is retained in the filter. To overcome this, a $\mathrm{Fe}^{3+} / \mathrm{Oxalate}$ process was proposed. Process efficiency was evaluated for variables such as $\mathrm{Fe}^{3+}$ concentration and $\mathrm{pH}$, using a compound parabolic collector (CPC) photoreactor at lab-scale under simulated solar radiation. The effect of the matrix was also tested by spiking OTC into two different real wastewaters.
\end{abstract}

\section{INTRODUCTION}

Antibiotics are a special group of pharmaceuticals used to control infection diseases in human and veterinary medicine. Residual concentration have been detected in various environmental compartments worldwide due to the fact that a large percentage of the consumed antibiotics are not completely metabolized (and thus are excreted as active substances) and that conventional wastewater treatment methods fail to completely remove them from solution (Kümmerer, 2009).

Advanced oxidation processes (AOPs), a class of treatments involving different ways of generating the highly reactive and non-selective hydroxyl radical $\left({ }^{\circ} \mathrm{OH}\right)$ and other reactive oxygen species (Gogate and Pandit, 2004), have been considered for the removal of these substances, especially those involving catalysis and solar irradiation such as the photo-Fenton process (Homem and Santos, 2011). Photo-Fenton comprises the combination of ferrous iron $\left(\mathrm{Fe}^{2+}\right)$ with hydrogen peroxide $\left(\mathrm{H}_{2} \mathrm{O}_{2}\right)$ and (solar) UV-Vis radiation resulting in the production of two moles of ${ }^{\circ} \mathrm{OH}$ per mole of hydrogen peroxide (Eq. 1 and 2), as simplified by Gogate and Pandit (2004): 


$$
\begin{aligned}
& \mathrm{Fe}^{2+}+\mathrm{H}_{2} \mathrm{O}_{2} \rightarrow \mathrm{Fe}^{3+}+{ }^{\bullet} \mathrm{OH} \\
& \mathrm{Fe}^{3+}+h \mathrm{v} \rightarrow \mathrm{Fe}^{2+}+{ }^{\bullet} \mathrm{OH}
\end{aligned}
$$

Pertinent to this process is the formation of stable complexes between antibiotics such as Oxytetracycline (OTC) and Fe (II) and Fe (III) (Figueroa and Mackay, 2005). It not only decreases degradation efficiencies (due to a lower iron availability to react with hydrogen peroxide), but it may also lead to mistaken readings in analytical equipments. However, this can be overcome by recurring to complexation of Fe (III) with carboxylate ions, which also improves the photo-Fenton process by extending the solubility of iron to higher and more practical $\mathrm{pH}$ values, by presenting stronger radiation absorption at wavelengths until $580 \mathrm{~nm}$ and by increasing the quantum yield of $\mathrm{Fe}^{2+}$ production according to Eq. 3 (Pignatello et al., 2006).

$$
\mathrm{Fe}^{3+}\left(\mathrm{C}_{2} \mathrm{O}_{4}\right)_{n}^{(3-2 n)}+h v \rightarrow \mathrm{Fe}^{2+}+(n-1) \mathrm{C}_{2} \mathrm{O}_{4}^{2-}+\mathrm{C}_{2} \mathrm{O}_{4}^{2-\bullet}
$$

In this context, the aim of this work was the process intensification at near neutral $\mathrm{pH}$ conditions of a homogeneous solar photo-Fenton reaction through the use of ferrioxalate complexes applied to the removal of Oxytetracycline in aqueous solutions. Experiments at lab-scale using a CPC photoreactor under simulated solar radiation were performed to i) compare the conventional $\mathrm{Fe}^{2+} / \mathrm{H}_{2} \mathrm{O}_{2} / \mathrm{UV}$-Vis with the $\mathrm{Fe}^{3+} / \mathrm{Oxalate} \mathrm{H}_{2} \mathrm{O}_{2} / \mathrm{UV}-\mathrm{V}$ is system, ii) choose the optimum dissolved Fe (III) concentration (iron/oxalate molar ratio of 1:3) and also iii) the initial working $\mathrm{pH}$ level. Matrix effects were studied by spiking OTC in two different media, a WWTP effluent after secondary treatment and a real troutfarm effluent.

\section{EXPERIMENTAL}

The experiments were carried out in a lab-scale photoreactor provided with a sunlight simulator. A schematic representation and a detailed description can be consulted elsewhere (Soares et al., 2013). A stirred tank was filled with $20 \mathrm{mg} \mathrm{L}^{-1}$ OTC solution (total volume $\left.\left(V_{\mathrm{t}}\right)=1.2 \mathrm{~L}\right)$. This solution was continuously pumped with a peristaltic pump to a Duran reactor equipped with a CPC collector (illuminated volume $\left(V_{\mathrm{i}}\right)=270 \mathrm{~mL}$; collector area $\left(A_{\mathrm{CPC}}\right)=0.023 \mathrm{~m}^{2}$ ) placed inside an ATLAS SUNTEST CPS + , and recirculated to the tank at a flow rate of $0.65 \mathrm{~L} \mathrm{~min}^{-1}$. The thermostatic bath was set to keep the solution temperature at $25^{\circ} \mathrm{C}$. After $15 \mathrm{~min}$, a sample was taken to confirm initial OTC and Dissolved Organic Carbon (DOC) concentrations. In the $\mathrm{Fe}^{2+} / \mathrm{H}_{2} \mathrm{O}_{2} / \mathrm{UV}-\mathrm{Vis}$ experiments, the initial $\mathrm{pH}$ was adjusted to 3.0, 4.0 or 5.0 with sulfuric acid and another sample was taken after 15 min. Iron (II) sulfate was added in order to achieve a concentration of $2 \mathrm{mg} \mathrm{L}^{-1} \mathrm{Fe}$ (II). The solution was left to homogenize for $15 \mathrm{~min}$, after which another sample was taken, and the initial iron concentration was also confirmed. Immediately after irradiation began, an initial $30 \mathrm{mg} \mathrm{L}^{-1}$ $\mathrm{H}_{2} \mathrm{O}_{2}$ dose was added (it kept between 10 and $30 \mathrm{mg} \mathrm{L}^{-1}$, with a total addition around $2 \mathrm{mM}$ ), while the $\mathrm{pH}$ of the solution was left uncontrolled. The same procedure was followed in the $\mathrm{Fe}^{3+} / \mathrm{Oxalate} / \mathrm{H}_{2} \mathrm{O}_{2} / \mathrm{UV}-\mathrm{Vis}$ experiments, except for the addition of a 1:3 iron/oxalate molar ratio dose, before the $\mathrm{pH}$ adjustment and iron (III) chloride addition steps. The solution was left to homogenize for $15 \mathrm{~min}$, after which another sample was taken, and the initial iron concentration was also confirmed. The light source was a vapour Xenon lamp $(300 \mathrm{~nm}<\lambda$ 


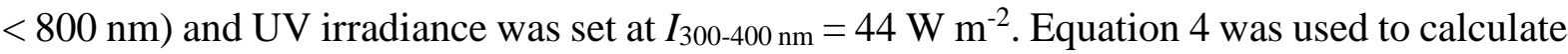
the accumulated UV energy $\left(Q_{U V, n}, \mathrm{~kJ} \mathrm{~L}^{-1}\right)$ received on any surface in the same position regarding the lamp, per unit of volume of water inside the reactor, in time interval $\Delta t$ :

$$
Q_{U V, n}=Q_{U V, n-1}+\Delta t_{n} \overline{U V}_{G, n} \frac{A_{r}}{1000 \times V_{t}} ; \quad \Delta t_{n}=t_{n}-t_{n-1}
$$

where $t_{n}$ is the experimental time of each sample (s), $V_{t}$ the total reactor volume (L), $A_{r}$ the illuminated collector surface area $\left(\mathrm{m}^{2}\right)$ and $\overline{U V}_{G, n}$ the average solar ultraviolet radiation (W $\mathrm{m}^{-2}$ ) measured during the period $\Delta t_{n}(\mathrm{~s})$.

Matrix effects were studied by spiking OTC in two different effluents (main characteristics in Table 1), and compared to the analogous results obtained using deionized water (DW). Wastewater effluent (WW) was collected after secondary treatment in a urban WWTP (Northern Portugal), while trout farm effluent (TF) was collected in the outlet of a trout farm operated in open circuit regime (Northern Portugal), after final decantation.

\begin{tabular}{|c|c|c|c|c|c|}
\hline \multirow[t]{2}{*}{ Effluent } & \multirow[t]{2}{*}{$\mathrm{pH}$} & \multirow{2}{*}{$\begin{array}{c}\mathrm{DOC} / \mathrm{IC} \\
\left(\mathrm{mg} \mathrm{L}^{-1}\right)\end{array}$} & \multicolumn{3}{|c|}{ Average anion concentrations $\left(\mathrm{mg} \mathrm{L}^{-1}\right)$} \\
\hline & & & {$\left[\mathrm{PO}_{4}{ }^{3-}\right]$} & {$\left[\mathrm{Cl}^{-}\right]$} & {$\left[\mathrm{SO}_{4}{ }^{2-}\right]$} \\
\hline WW & 6.46 & $5.5 / 5.1$ & 13.5 & 61.5 & 42.9 \\
\hline TF & 6.70 & $3.9 / 1.8$ & 0.95 & & \\
\hline
\end{tabular}

Antibiotic degradation was followed by HPLC-DAD, its mineralization by DOC removal, $\mathrm{H}_{2} \mathrm{O}_{2}$ and total dissolved iron concentrations were determined colorimetrically using the vanadate and 1,10-phenantroline methods, respectively. A pseudo-first-order mathematical model was used to describe the experimental kinetic data using a non-linear regression method.

\section{RESULTS AND DISCUSSION}

\subsection{Conventional $\mathrm{Fe}^{2+} / \mathrm{H}_{2} \mathrm{O}_{2} / \mathrm{UV}$-Vis Reaction}

The results of the conventional $\mathrm{Fe}^{2+} / \mathrm{H}_{2} \mathrm{O}_{2} / \mathrm{UV}$-Vis degradation of OTC under different initial $\mathrm{pH}$ values (3.0, 4.0 and 5.0) are shown in Figure 1. The concentration of Fe (II) was $2 \mathrm{mg} \mathrm{L}^{-1}$, which is the total iron discharge limit into any water body, according to the Portuguese legislation (D-L 236/98). In the three experiments, after the first addition of $\mathrm{H}_{2} \mathrm{O}_{2}$, the concentration of OTC approached LOQ levels approximately after 4 min of illumination $\left(0.22 \mathrm{kJUV} \mathrm{L}^{-1}\right)$. The DOC levels slowly decreased down to near $30 \%$ of their initial values by the end of the photo-treatment period (45 $\min , 2.7 \mathrm{~kJ}_{\mathrm{UV} \mathrm{L}}{ }^{-1}$ ), while an average of $1.5 \mathrm{mM}$ of $\mathrm{H}_{2} \mathrm{O}_{2}$ was consumed.

Taking into consideration Eq. 1, after the Fe (II) oxidation step to Fe (III), the rapid decay of the antibiotic may be explained by the formation of stable complexes between OTC and Fe (III), which strongly interferes with HPLC measurements (Figueroa and Mackay, 2005) and may thus induce in erroneous kinetic calculations. Overall stability constants of the Fe (II)OTC and Fe (III)-OTC complexes of 10.4 and 22.0, respectively (Albert, 1953), support this conclusion. We have attempted to model the complex formation between OTC and Fe (III) using the equilibrium computer program MINEQL+ (Schecher and McAvoy, 2003). As it can 
be seen in Fig. 1b (left), a large fraction of Fe (III) is expected to form complexes with the antibiotic. Bench-scale tests confirmed that by increasing the $\mathrm{pH}$ from 3.0 towards 5.0 of solutions containing only $2 \mathrm{mg} \mathrm{L}^{-1} \mathrm{Fe}$ (III) and $20 \mathrm{mg} \mathrm{L}^{-1}$ of OTC, the original concentration of OTC not only gradually decreases but it also differs from filtered and non-filtered samples (data not shown). The same phenomenon occurs with DOC. As such, the complete removal of OTC from solution by the conventional photo-Fenton reaction with increasing initial $\mathrm{pH}$ values could not be directly attributed.

a)

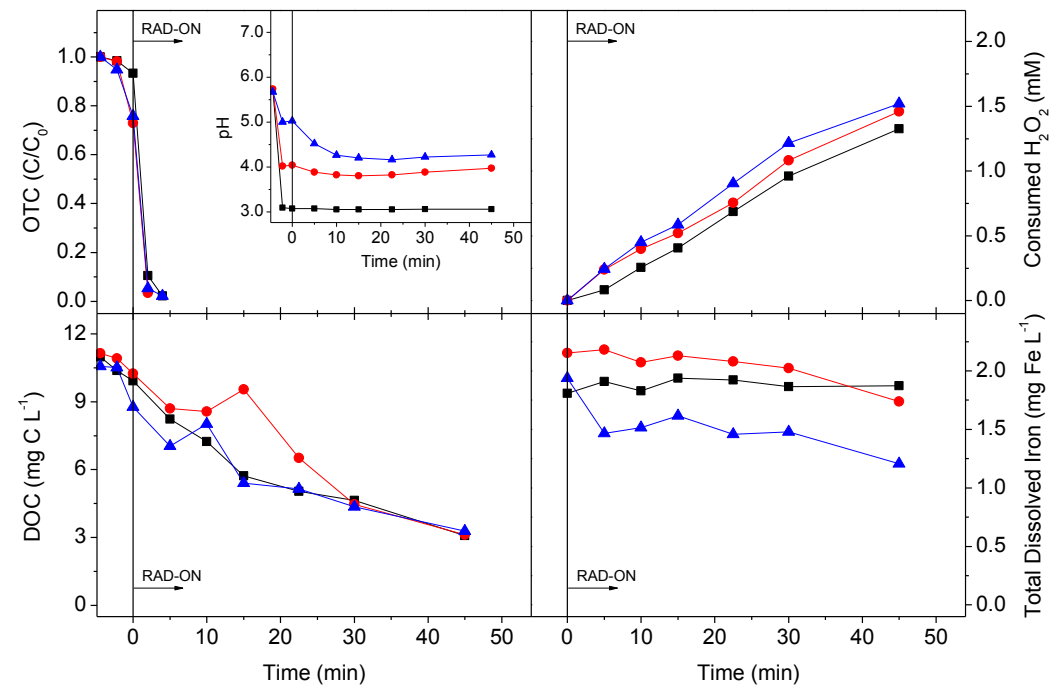

b)

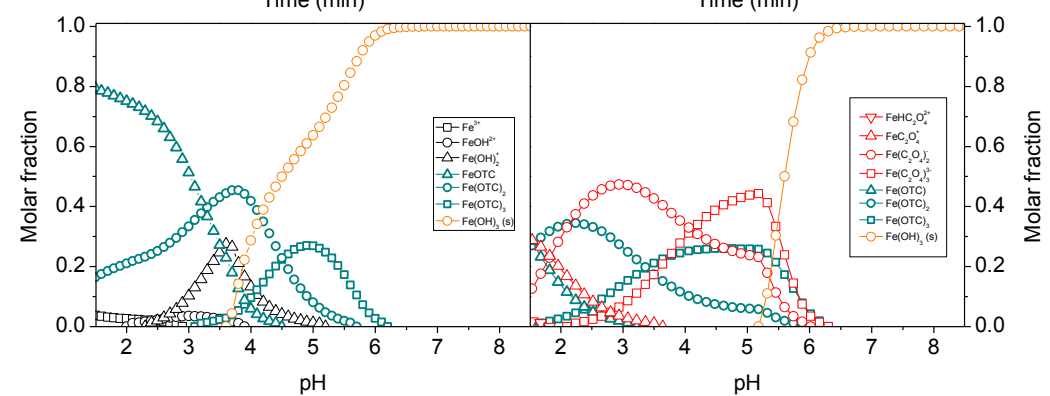

Figure 1 - a) Effect of initial $\mathrm{pH}(\boldsymbol{\bullet}-\mathrm{pH}=3.0 ; \bullet-\mathrm{pH}=4.0 ; \boldsymbol{\Delta}-\mathrm{pH}=5.0)$ on the degradation of OTC, DOC removal, $\mathrm{H}_{2} \mathrm{O}_{2}$ consumption, total dissolved iron and $\mathrm{pH}$ using the conventional solar photo-Fenton process mediated by $2 \mathrm{mg} \mathrm{L}^{-1} \mathrm{Fe}$ (II); b) Speciation diagrams for iron (III) as a function of $\mathrm{pH}$ in a solution containing $20 \mathrm{mg} \mathrm{L}^{-1}$ of OTC and $3.58 \times 10^{-2} \mathrm{mM}\left(2 \mathrm{mg} \mathrm{L}^{-1}\right)$ of Fe (III) without accounting (left) or accounting (right) for $1.07 \times 10^{-1} \mathrm{mM}\left(9.5 \mathrm{mg} \mathrm{L}^{-1}\right)$ oxalic acid. Ionic strength $=4 \mathrm{mM}$.

Silva et al. (2010) have demonstrated how the addition of organic ligands such as oxalate displace the herbicide tebuthiuron (TBH) from the non-photoactive Fe (III)-TBH complex, improving the degradation process of $\mathrm{TBH}$ via the photo-Fenton reaction. In this way, we have introduced the oxalate and iron-oxalate equilibrium reactions in MINEQL+ in order to calculate the formation of complexes between the same amount of Fe (III), OTC, and $9.5 \mathrm{mg} \mathrm{L}^{-1}$ oxalate (1:3 iron/oxalate ratio) present in solution. Fig. $1 \mathrm{~b}$ (right) shows that the added oxalate clearly competes with OTC for the available Fe (III) in the $\mathrm{pH}$ range of interest. The concentration of OTC can thus be properly followed by HPLC-DAD, which allows for a proper kinetic study. Taking this and the objective of operating this process at neutral $\mathrm{pH}$ values into consideration, the ability of oxalate to improve the photo-Fenton process was henceforth studied. 


\section{2. $\mathrm{Fe}^{3+} / \mathrm{Oxalate} / \mathrm{H}_{2} \mathrm{O}_{2} / \mathrm{UV}$-Vis OTC degradation reactions}

Influence of iron concentration: Fig. 2 presents the OTC degradation efficiency by the photo-Fenton reaction using low iron concentrations in the threshold of the iron discharge limit (1.0, 2.0 and $\left.5.0 \mathrm{mg} \mathrm{L}^{-1}\right)$, with an iron/oxalate molar ratio of 1:3, without initial $\mathrm{pH}$ adjustment.

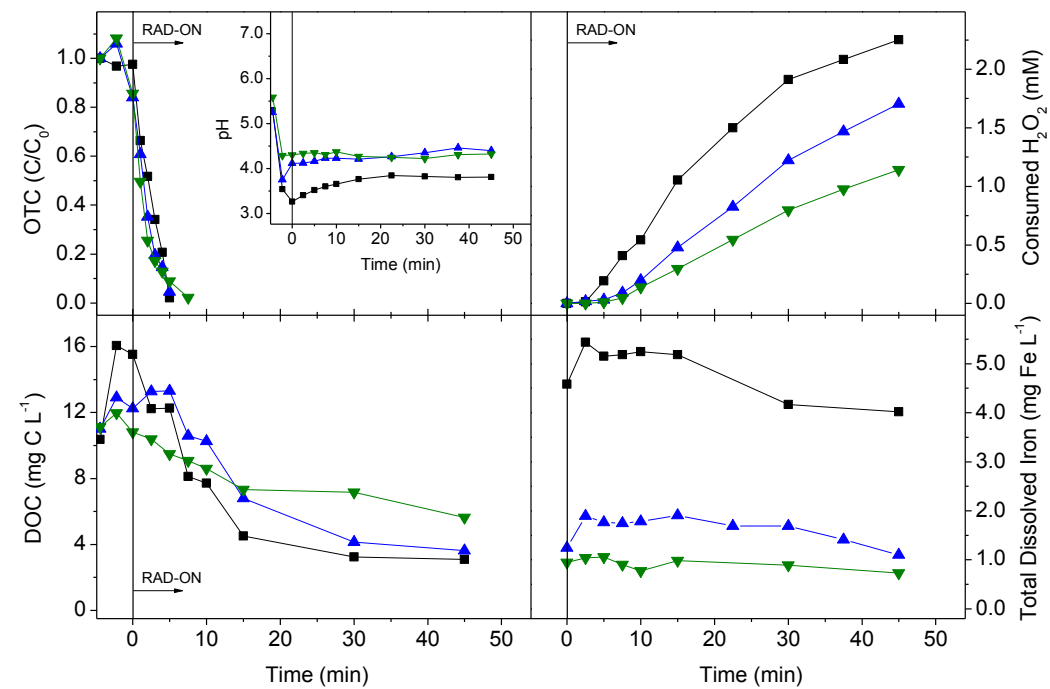

Figure 2 - Effect of Fe (III) concentration ( $\left.\boldsymbol{\nabla}-1.0 \mathrm{mg} \mathrm{L}^{-1} ; \boldsymbol{\Delta}-2.0 \mathrm{mg} \mathrm{L}^{-1} ; \boldsymbol{\square}-5.0 \mathrm{mg} \mathrm{L}^{-1}\right)$ on OTC degradation, DOC removal, $\mathrm{H}_{2} \mathrm{O}_{2}$ consumption, total dissolved iron and $\mathrm{pH}$ using the $\mathrm{Fe}^{3+} / \mathrm{Oxalate} / \mathrm{H} 2 \mathrm{O} 2 / \mathrm{UV}$ Vis system.

The degradation profiles were very similar for all tested Fe (III) concentrations. Even with the lowest tested concentration, OTC was no longer detected (LOD $=0.10 \mathrm{mg} \mathrm{L}^{-1}$ ) after $10 \mathrm{~min}$ of reaction $\left(\sim 0.6 \mathrm{~kJ}_{\mathrm{UV} \mathrm{L}} \mathrm{L}^{-1}\right)$. By the end of the photo-treatment period $(45 \mathrm{~min}$, $2.75 \mathrm{~kJ}_{\mathrm{Uv} \mathrm{L}}{ }^{-1}$ ), $80 \%$ mineralization was achieved with both 2 and $5 \mathrm{mg} \mathrm{L}^{-1}$ of $\mathrm{Fe}$ (III), although a higher $\mathrm{H}_{2} \mathrm{O}_{2}$ consumption occurred with the highest $\mathrm{Fe}$ (III) concentration. In contrast, for $1 \mathrm{mg} \mathrm{L}^{-1}$ of $\mathrm{Fe}$ (III) only $~ 50 \%$ mineralization was achieved, with less $\mathrm{H}_{2} \mathrm{O}_{2}$ consumed than for the other Fe (III) concentrations. A direct relationship between the increases in ${ }^{\circ} \mathrm{OH}$ formation and the Fe dosage is expected according to Eq. 1. The avoidance of the need of an iron removal step at the end of the treatment, associated with a satisfying mineralization degree, has shown $2 \mathrm{mg} \mathrm{L}^{-1}$ to be the concentration that represented the working option for photo-Fenton treatment with Fe (III)-oxalate complex. The pseudo-first order kinetic rate constant of the $2 \mathrm{mg} \mathrm{L}^{-1}$ experiment, $8.6 \pm 0.5 \mathrm{~L} \mathrm{~kJ}^{-1}$, was the double of the rate constant reported in our previous work regarding the solar photocatalytic degradation of OTC in the presence of $0.5 \mathrm{~g} \mathrm{~L}^{-1} \mathrm{TiO}_{2}$ at a neutral $\mathrm{pH}$, carried out with the same experimental installation, $4.3 \pm 0.4 \mathrm{~L} \mathrm{~kJ}^{-1}$ (Pereira et al., 2013).

Influence of initial solution $\mathrm{pH}$ : The effect of the initial solution $\mathrm{pH}$ value was then studied in order to find the highest possible working $\mathrm{pH}$ without compromising reaction efficiency. The results, presented in Fig. 3, show that with unadjusted initial $\mathrm{pH}(\sim 4.1)$, $\mathrm{pH}=5.0$ and $\mathrm{pH}=6.0$, OTC was no longer detected after 5, 10 and $15 \mathrm{~min}$ of illumination time $\left(0.3,0.6\right.$ and $0.9 \mathrm{~kJ} \mathrm{~L}^{-1}$ of $Q_{\mathrm{Uv}}$, respectively). By the same order, DOC concentration was reduced by 75,51 and $37 \%$ of its initial value after $45 \mathrm{~min}$ of reaction $\left(2.78 \mathrm{~kJ}_{\mathrm{UV} \mathrm{L}} \mathrm{L}^{-1}\right)$. The decreasing reaction rates at $\mathrm{pH} \sim 4.1, \mathrm{pH}=5.0$ and $\mathrm{pH}=6.0$ experiments, $8.6 \pm 0.5,6.3 \pm 0.2$ and $2.3 \pm 0.1 \mathrm{~L}^{-1} \mathrm{~kJ}$, respectively, appear to reflect the relationship between the molar fractions 
of the referred iron-oxalate complexes and their respective quantum yields (at $436 \mathrm{~nm}, 1.40$ for $\mathrm{Fe}\left(\mathrm{C}_{2} \mathrm{O}_{4}\right)_{2}{ }^{-}$and 1.00 for $\mathrm{Fe}\left(\mathrm{C}_{2} \mathrm{O}_{4}\right)_{3}{ }^{3-}$ (Weller et al., 2013). Cumulatively, $\mathrm{Fe}\left(\mathrm{C}_{2} \mathrm{O}_{4}\right)_{2}{ }^{-}$and $\mathrm{Fe}\left(\mathrm{C}_{2} \mathrm{O}_{4}\right)_{3}{ }^{3-}$ are the main iron species in the studied $\mathrm{pH}$ range, albeit with changing proportions over $\mathrm{pH}$ (Fig.1b, right). At $\mathrm{pH}=6.0$, total iron precipitation would be expected. However, this precipitation occurs slowly, and Fe (III) may not be in equilibrium with the solid phase (Balmer and Sulzberger, 1999), so some oxalate is still expected to be found in solution. The working $\mathrm{pH}$ of 5.0 was thus chosen for the subsequent experiments, since no extra dosage of oxalic acid was needed to obtain a satisfactory $49 \%$ mineralization of the initial DOC content, OTC was no longer detected after 10 min of illumination time $\left(Q_{\mathrm{UV}}=0.6 \mathrm{~kJ} \mathrm{~L}^{-1}\right)$, and the final $\mathrm{pH}$ value of the solution approached the legal lower discharge $\mathrm{pH}$ value of 6.0 (D-L 236/98).

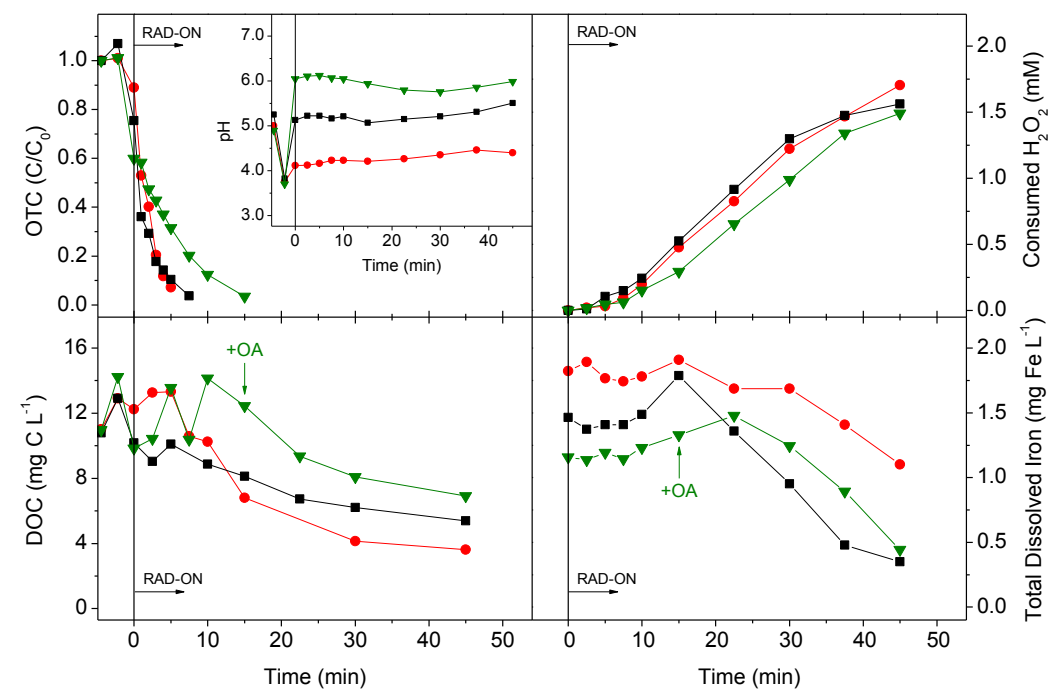

Figure 3 - Effect of initial $\mathrm{pH}\left(\bullet-\mathrm{pH}_{0} \sim 4.0 ; \boldsymbol{-}-\mathrm{pH}_{0}=5.0 ; \boldsymbol{\nabla}-\mathrm{pH}_{0}=6.0\right)$ on OTC degradation, DOC removal, $\mathrm{H}_{2} \mathrm{O}_{2}$ consumption, total dissolved iron and $\mathrm{pH}$ using $\mathrm{Fe}^{3+} / \mathrm{Oxalate} / \mathrm{H} 2 \mathrm{O} 2 / \mathrm{UV}-\mathrm{Vis}$ system.

Influence of the matrix: Even though $\mathrm{pH}_{0}=5.0$ was set beforehand, experiments were also performed with $\mathrm{pH}_{0}=4.0$ in each media. This was due to the fact that after the oxalate and iron (III) addition steps, the $\mathrm{pH}$ of the TF effluent lowered to the same unadjusted $\mathrm{pH}$ of the DW solution, around 4.0. In Figure 4a, it can be seen that with $\mathrm{pH}_{0}=4.0$, OTC was no longer detected after $10 \mathrm{~min}$ of illumination in WW $\left(Q_{\mathrm{UV}}=0.7 \mathrm{~kJ} \mathrm{~L}^{-1}\right)$, and after $6 \mathrm{~min}$ in TF $\left(Q_{\mathrm{UV}}=0.4 \mathrm{~kJ} \mathrm{~L}^{-1}\right)$. Required illumination times were higher in $\mathrm{pH}_{0}=5.0: 20 \mathrm{~min}$ in WW $\left(Q_{\mathrm{UV}}=1.4 \mathrm{~kJ} \mathrm{~L}^{-1}\right)$, and $10 \mathrm{~min}$ in $\mathrm{TF}\left(Q_{\mathrm{UV}}=0.7 \mathrm{~kJ} \mathrm{~L}^{-1}\right)$. Distribution of the iron (III) species in both media (Fig. 4b) seems to explain the similar kinetic degradation rates achieved with TF $\left(\mathrm{pH}_{0}=4.0: 9.59 \pm 0.04 ; \mathrm{pH}_{0}=5.0: 5.6 \pm 0.4 \mathrm{~L} \mathrm{~kJ}^{-1}\right)$, and the worse with $\mathrm{WW}\left(\mathrm{pH}_{0}=4.0\right.$ : $3.7 \pm 0.3 ; \mathrm{pH}_{0}=5.0: 1.5 \pm 0.2 \mathrm{~L} \mathrm{~kJ}^{-1}$ ). At $\mathrm{pH}_{0}=4.0$, some fraction of iron (III) in the form of the mineral Strengite $\left(\mathrm{FePO}_{4} \cdot 2 \mathrm{H}_{2} \mathrm{O}(\mathrm{s})\right)$ is already expected to be found in $\mathrm{WW}$, while in TF medium results, there is a relatively higher proportion of the more photo-active $\mathrm{Fe}\left(\mathrm{C}_{2} \mathrm{O}_{4}\right)_{2}{ }^{-}$ complex compared to that in DW (Fig. 4b). The proportion of $\mathrm{FePO}_{4} .2 \mathrm{H}_{2} \mathrm{O}$ (s) at $\mathrm{pH}_{0}=5.0$ in both effluents clearly reflects the lower OTC kinetic degradation rates, especially in the case of WW effluent. Also to be considered is the effect of the additional DOC content of both effluents in the overall process efficiency. Compared to the DW experiments, for instance, less $\mathrm{H}_{2} \mathrm{O}_{2}$ was consumed by the end of the photo-treatment period (Fig. 4a), which may also reflect the lesser reduction in DOC content comparing with DW experiments at both tested $\mathrm{pH}$ values. 
Accounting for each effluent's initial DOC values, DOC reduction in WW was of 39 and 31\% for $\mathrm{pH}_{0}=4.0$ and 5.0, respectively, whereas in $\mathrm{TF}$ it was 56 and 49\%, in the same order.

a)

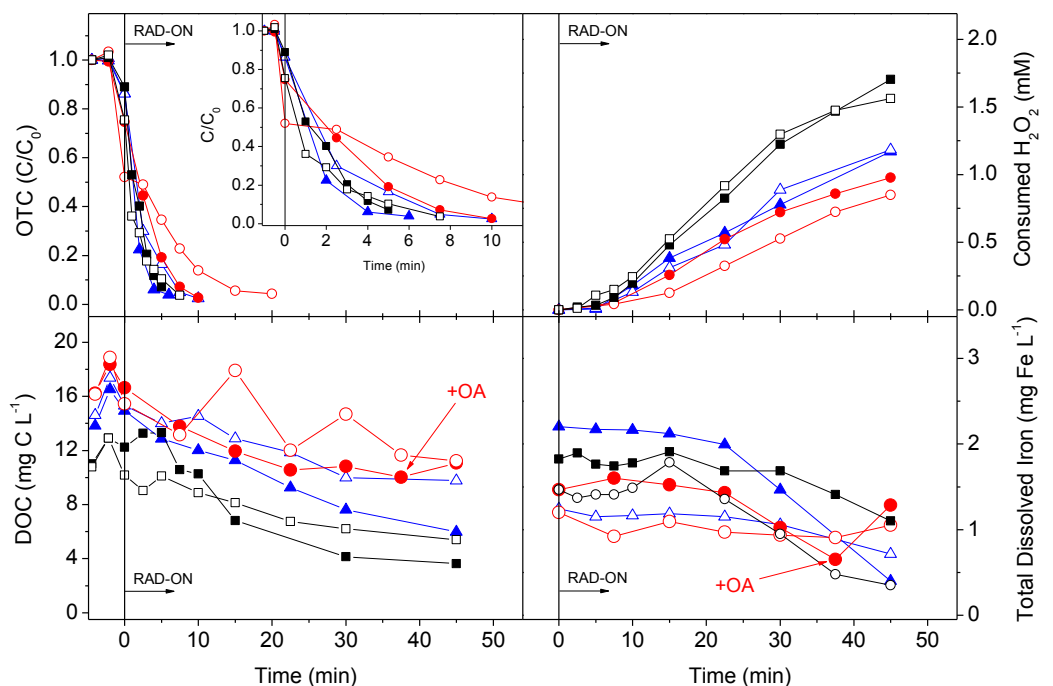

b)

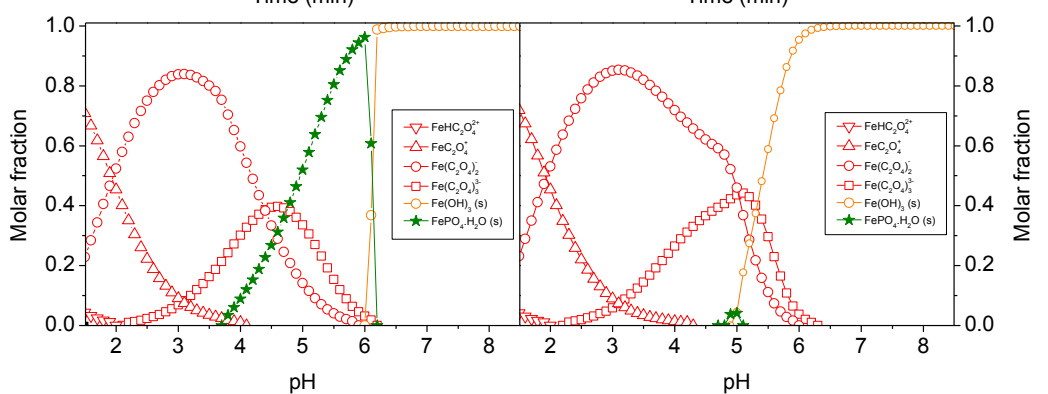

Figure 4 - a) Effect of the matrix on OTC degradation, DOC removal, $\mathrm{H}_{2} \mathrm{O}_{2}$ consumption and total dissolved iron using the $\mathrm{Fe}^{3+} / \mathrm{Oxalate} / \mathrm{H} 2 \mathrm{O} 2 / \mathrm{UV}-\mathrm{V}$ is system, performed at $\mathrm{pH}_{0}=4.0$ (closed symbols) and $\mathrm{pH}_{0}=5.0$ (open symbols). Matrixes: DW $(\boldsymbol{\bullet}, \square), \mathrm{TF}(\boldsymbol{\Delta}, \triangle) \mathrm{WW}(\bullet, \circ)$; b) Speciation diagram for iron (III) as a function of $\mathrm{pH}$ in WW (left) and TF (right) effluents, containing $1.07 \times 10^{-1} \mathrm{mM}\left(9.5 \mathrm{mg} \mathrm{L}^{-1}\right)$ oxalic acid and $3.58 \times 10^{-2} \mathrm{mM}\left(2 \mathrm{mg} \mathrm{L}^{-1}\right)$ of $\mathrm{Fe}$ (III). Ionic strength $=3 \mathrm{mM}$.

\section{CONCLUSIONS}

In this work, it was shown how the highly photo-active ferricarboxylate complexes successfully promotes the photo-Fenton reaction in a lab-scale apparatus simulating solar radiation, equipped with a CPC photo-reactor, to remove the antibiotic Oxytetracycline from aqueous solution at near-neutral $\mathrm{pH}$ values.

The oxalic acid in a 1:3 iron/oxalate molar ratio with the aim of forming iron/oxalate complexes showed to deter the inconvenient formation of Fe:OTC complexes, which undermine OTC analytical detection and hamper the regeneration of Fe (III) into Fe (II). Good antibiotic and DOC removals were achieved using the maximum allowed iron concentration in treated effluents $\left(2 \mathrm{mg} \mathrm{L}^{-1}\right.$ of $\mathrm{Fe}$ (III)), oxalic acid in a 1:3 iron/oxalate molar ratio, and the initial $\mathrm{pH}$ of 5.0, requiring overall low accumulated UV energy per liter of solution. Experiments performed in a domestic WWTP effluent showed slower OTC removal kinetics and lower DOC reduction mainly due to the precipitation of $\mathrm{FePO}_{4}$. However, in a less complex 
effluent from the outlet of a trout farm it was shown that without the $\mathrm{pH}$ adjustment step, similar results were achieved, compared with deionized water experiments.

\section{ACKNOWLEDGMENTS}

This work was partially supported by projects PEst-C/EQB/LA0020/2013, PTDC/AACAMB/113091/2009 and AQUAPHOTOBIO - PP-IJUP-2011-180, financed by FEDER through COMPETE - Programa Operacional Factores de Competitividade, by FCT - Fundação para a Ciência e a Tecnologia and U. Porto/Banco Santander Totta. J.H.O.S. Pereira acknowledges his doctoral fellowship (SFRH/BD/62277/2009) supported by FCT - Fundação para a Ciência e a Tecnologia. V.J.P. Vilar acknowledges the FCT Investigator 2013 Programme (IF/01501/2013).

\section{REFERENCES}

Decreto-Lei n. ${ }^{\circ}$ 236/98 de 1 de Agosto 1998, in, Diário da República - I Série-A, Portugal, pp. 3676-3722.

ALBERT, A. Avidity of Terramycin and Aureomycin for Metallic Cations. Nature 172, 201201, 1953.

BALMER, M.E., SULZBERGER, B. Atrazine degradation in irradiated iron/oxalate systems: Effects of pH and oxalate. Environ. Sci. Technol. 33, 2418-2424, 1999.

FIGUEROA, R.A., MACKAY, A.A. Sorption of oxytetracycline to iron oxides and iron oxiderich soils. Environ. Sci. Technol. 39, 6664-6671, 2005.

GOGATE, P.R., PANDIT, A.B. A review of imperative technologies for wastewater treatment II: Hybrid methods. Adv. Environ. Res. 8, 553-597, 2004.

HOMEM, V., SANTOS, L. Degradation and removal methods of antibiotics from aqueous matrices - A review. J. Environ. Manage. 92, 2304-2347, 2011.

KÜMMERER, K. The presence of pharmaceuticals in the environment due to human use present knowledge and future challenges. J. Environ. Manage. 90, 2354-2366, 2009.

PEREIRA, J.H.O.S., REIS, A.C., QUEIRÓS, D., NUNES, O.C., BORGES, M.T., VILAR, V.P., BOAVENTURA, R.A.R. Insights into solar $\mathrm{TiO}_{2}$-assisted photocatalytic oxidation of two antibiotics employed in aquatic animal production, oxolinic acid and oxytetracycline. Sci. Total Environ. 463-464, 274-283, 2013.

PIGNATELLO, J.J., OLIVEROS, E., MACKAY, A. Advanced oxidation processes for organic contaminant destruction based on the fenton reaction and related chemistry. Crit. Rev. Environ. Sci. Technol. 36, 1-84, 2006.

SCHECHER, W.D., MCAVOY, D.C., MINEQL+: A Chemical Equilibrium Modeling System, Version 4.5 for Windows, in, Environmental Research Software, Hallowell, Maine, 2003.

SILVA, M.R.A., VILEGAS, W., ZANONI, M.V.B., PUPO NOGUEIRA, R.F. Photo-Fenton degradation of the herbicide tebuthiuron under solar irradiation: Iron complexation and initial intermediates. Water Res. 44, 3745-3753, 2010.

SOARES, P.A., SILVA, T.F.C.V., MANENTI, D.R., SOUZA, S.M.A.G.U., BOAVENTURA, R.A.R., VILAR, V.J.P. Insights into real cotton-textile dyeing wastewater treatment using solar advanced oxidation processes. Env. Sci. Pollut. Res. 1-14, 2013.

WELlER, C., HORN, S., HERRMANN, H. Effects of Fe(III)-concentration, speciation, excitation-wavelength and light intensity on the quantum yield of iron(III)-oxalato complex photolysis. J. Photochem. Photobiol. A: Chem. 255, 41-49, 2013. 